\title{
GAME MOTORIK : PETUALANGAN SI ENTONG, MENGENAL MAKANAN BERGIZI
}

\author{
Haikal Ahkam Purliano', Endah Sudarmilah ${ }^{2}$ \\ ${ }^{1,2)}$ Program Studi Informatika, Universitas Muhammadiyah Surakarta \\ Email:"ahkamhaikal@gmail.com, ²endah.sudarmilah@ums.ac.id
}

(Naskah masuk: 25 Oktober 2019, diterima untuk diterbitkan: 8 November 2019)

\begin{abstract}
ABSTRAK
Hampir setiap orang pasti pernah melakukan aktivitas atau kegiatan bermain game untuk sekedar mencari kesenangan atau membuang kejenuhan. Dunia digital yang berkembang pesat berdampak langsung terhadap perkembangan game yang beragam sehingga berpotensi memunculkan dampak negatif terhadap anak-anak. Salah satunya membuat tergesernya arena permainan anak-anak oleh banyaknya permainan di smartphone atau komputer, alhasil anak kekurngan permainan yang mampu meningkatkan perkembangannya dari segi kreativitas, bahasa, emosi, motorik, sikap hidup dan nilai sosial. Motorik kasar menjadi penting, fisik motoric anak akan berpengaruh terhadap kemampuan anak dalam menggunakan dan mengendalikan gerakan secara optimal. Tak sedikit yang menganggap bermain game sama dengan membuang-buang waktu dan tidak memiliki manfaat yang bagus. Seiring dengan perkembangan teknologi yang pesat menjadikan game untuk menarik minat anak dalam belajar bisa menjadi alternatif lain dengan mengembangkan aplikasi game edukasi agar anak lebih tertarik untuk belajar dan tidak mudah jenuh sekaligus dapat memenuhi kebutuhan bermain anak yang mampu mengasah otak atau dalam hal nilai-nilai lainnya. Metode penelitian ini dilakukan dengan penerapan metode SDLC model Waterfall membentuk serangkaian fase yang diterapkan pada proses penelitian dan pengembangan game edukasi. Aplikasi diuji dengan menggunakan Black Box Testing, untuk menjukan bahwa game edukasi sudah berjalan sesuai spesifikasi kebutuhan. Hasil pengujian menggunakan Black Box Testing menunjukan aplikasi game edukasi petualangan si entong, mengenal makanan bergizi telah sesuai dengan kebutuhan aplikasi.
\end{abstract}

Kata kunci: Aplikasi, Game, Edukasi, Motorik, Anak, Waterfall

\begin{abstract}
Almost everyone have played games just for fun activity or get rid of boredom somehow. The digital world were rapidly developing has a direct impact on the development of various games that have the potential to have a negative impact on children. One of them are makes the arena of children's playzone shifted by many games on smartphones or computers, as a result children lack of games that are able to improve their development in terms of creativity, language, emotions, motor skills, life attitudes and social values. Gross motor becomes a thing, the physical motor of the child will affect the child's ability to use and control movements optimally. Not the least who consider playing the game the same as wasting time and do not have good benefits. Along with the rapid development of technology, makes a game to attract children's interest in learning can be another alternative by developing educational game applications so that children are more interested in learning and not easily saturated all at once will fullfil children's play needs so children able to sharpen the brain or in terms of other values. The research method was carried out by applying the Waterfall model of SDLC method to form a series of phases that were applied to the process of research and development of educational games. This application is tested using Black Box Testing, to ensure that educational games run according to the requirements specifications. The results of testing using Black Box Testing show that the educational application of the adventure game entong, knowing nutritious food is in accordance with the needs of the application.
\end{abstract}

Keywords: Application, Game, Education, Motoric, Children, Waterfall 


\section{PENDAHULUAN}

Menurut (Masfufah et al., 2017) Game atau permainan merupakan sesuatu yang dimainkan dengan aturan tertentu dan ada pemin yang menang atau pemain yang kalah, biasanya memiliki sebagai penyegar dari kejenuhaan. Perkembangan game memiliki jenis yang beragam, seperti misalnya game strategi, adventure, arcade, puzzle, sport, dan lain sebagainya dikemas dalam berbagai macam bentuk konsol dan tentynya akan sangat menarik bagi setiap orang terutama bagi anak-anak (Abidin et al., 2017). Anak-anak sangat menyukai bermain, karena menurut anak-anak bermain merupakan aktifitas yang menyenangkan. Bermain memiliki peran penting sebagai kebutuhan perkembangan anak dalam bermacam aspek seperti motorik kognitif, kreativitas, bahasa, emosi, nilai sosial dan sikap hidup (Firdaus \& Nugroho, 2016). Motorik kasar anak menjadi hal yang penting dari keenam aspek perkembangan, karna dengan anak mengusai keterampilan bergerak akan berpengaruh terhadap kemampuan interaskinya dengan lingkungan disekitarnya (Devrizal et al., 2019).

Game memang menyenangkan dan mampu meningkatkan antusias bagi para pemainnya. Maka akan lebih mudah untuk mendapat dan mempertahankan perhatian penuh seseorang untuk jangka waktu yang lama (Al-Azawi et al., 2016). Tergesernya arena permaianan dikalangan anak-anak yang juga tergantikan oleh banyaknya permainan di smartphone, menjadikan anak-anak kekurangan jenis permainan yang bisa tetap mengasah otak, sebagai media melatih ketangkasan dalam berfikir cepat dan tepat (Prasetyo et al., 2017). diperlukan suatu metode yang efisien, agar mendapat manfaat yang optimal. Permasalahan tersebut dapat diatasi Metode ini dapat diwujudkan dengan memadukan antara teknologi, pembelajaran, dan bermain (Darmanto \& Sudarmilah, 2016).

Perkembangan ilmu teknologi saat ini semakin berkembang. Banyak teknologi yang kini memberikan banyak dampak positif dan meningkatkan tingkat keefektifitasan dalam melakukan aktifitas sehari hari (Rahman et al., 2017). Pembelajaran berbasis permainan adalah metodologi inovatif yang memanfaatkan potensi pendidikan yang ditawarkan oleh videogame pada permainan umum dan serius khususnya untuk meningkatkan proses pelatihan, sehingga memudahkan pengguna untuk mencapai pembelajaran yang termotivasi (Pérez et al., 2018). Menurut analisis data oleh (Papastergiou, 2009) menunjukkan pendekatan game lebih efektif dalam mempromosikan pengetahuan dan lebih memotivasi daripada pendekatan non-game. Meskipun demikian, banyak yang menyetujui pembelajaran berbasis game sebagai paradigma pembelajaran baru ditangguhkan karena kurang dikelola dengan baik (Jin et al., 2018). Bagi sebagian orang bermain game dianggap sebagai aktivitas yang kurang bermanfaat karena cederung membuang-buang waktu, hal tersebut juga berpotensi menghilangkan ketertarikan anak untuk belajar dengan serius dan akan berdampak buruk pada perkembangan otak anak.

(Kusuma \& Sudarmilah, 2016) Memastikan Pembelajaran menggunakan teknologi multimedia pada audio-visual ataupun software komputer merupakan media pembelajaran yang cukup efektif dan menarik untuk meningkatkan mutu pembelajaran di dunia pendidikan. Namun, ada kesenjangan dalam literatur tentang dimensi inti Game Based-Learning (GBL) untuk desain, analisis, dan evaluasi yang komprehensif karena penggunaan elemen yang tidak konsisten (Tahir \& Wang, 2020). 
Memperhatikan hal tersebut penulis membuat game edukasi berbasis kompter untuk anak-anak, dirancang dengan menerapkan metode SDLC (Software Development Life Cycle) model Waterfall, yang diujikan melalui Black Box Testing, dengan harapan aplikasi game edukasi tersebut mampu memenuhi spesifikasi kebutuhan dan mampu menarik perhatian anak ataupun dapat mengubah pola belajar agar tidak membosankan sekaligus melatih kemampuan anak.

\section{METODE}

Metode Waterfall memiliki suatu proses pengembangan perangkat lunak yang berurutan, yang proses pengerjaannya terus mengalir dari atas ke bawah (mirip air terjun) melalui fase-fase Requirements (analisis kebutuhan), Design (perancangan dan pemodelan), Implementation (penerapan), Verification (pengujian), dan Maintenance (pemeliharaan) (Putra et al., 2016). Rangkaian fase yang digunakan penulis antara lain :

\section{A. Analisis Kebutuhan}

Dikutip dari (Putra et al., 2016) Langakah ini adalah analisa terhadap kebutuhan sistem. Pengumpulan data bias dilakukan dengan melakukan sebuah penelitian, wawancara atau studi literatur. Dalam hal ini penulis merumuskan analisis kebutahan fungsional dan non-fungsional.

Kebutuhan fungsional mencakup storyline, user, genre, dan interaksi

1. Storyline

Storyline adalah alur cerita seperti apa yang akan dibuat atau diterapkan dalam permainan selama berlangsung agar permainan tidak membosankan. Pada dasarnya pemainan yang penulis buat memiliki tiga tingkatan level. Storyline yang penulis rancang pada level 1 berisi tentang pengenalan makanan yang memiliki kandungan protein tinggi. Permainan akan bekahir jika user berhasil mengumpulkan 30 poin atau kehabisan nyawa. Pada level 2 berisi tentang pengenalan makanan sumber vitamin seperti buah dan sayur, permainan akan berakir apabila user berasil memilih makanan yang sesuai dengan gambar atau tulisan dengan syarat nyawa yang dimiki tidak sama dengan nol. Level 3 mengkategorikan makanan sehat dan tidak sehat yang memiliki kandungan karbohidrat tinggi, permainan akan selesai apabila poin mencapai 30 atau nyawa yang dimikili sama dengan nol.

2. User

User adalah pengguna atau pemain yang akan menggunakan aplikasi, subjek dari penelitian penulis adalah anak sekolah dasar yang sedang mempelajari tentang beberapa makanan-makanan empat sehat lima sempurna

3. Genre

Genre yang digunakan pada aplikasi ini adala permainan interaktif bergenre edukasi. Permainan ber-genre edukasi mengandung unsur pembelajaran atau memberikan sedikit atau banyak pengetahuan untuk penggunanya

4. Interaksi

Interaksi yang berlangsung dengan pengguna antara lain memiliki gambar yang bergerak, memainkan beragam musik dan efek suara, menampilkan poin dan nyawa yang tersisa secara langsung.

Kebutuhan non-fungsional pada aplikasi ini membutuhkan beberapa perangkat keras dan perangkat lunak, dapat dilihat pada tabel 2 .

Tabel 2. Kebutuhan Perangkat keras dan Perangkat lunak 


\begin{tabular}{lll}
\hline Perangkat Keras & Perangkat Lunak \\
\hline 1. Komputer / & 1. & Sistem \\
Laptop & oprasi \\
2. Proyektor & Windows \\
3. Step pad & 2. Adobe \\
& Illustrator \\
& $\begin{array}{l}\text { 3. } \\
\text { 4. }\end{array}$ \\
& $\begin{array}{l}\text { Aplikasi } \\
\text { JoyToKey } \\
\end{array}$ \\
& 5. NW.js \\
\hline
\end{tabular}

\section{B. Desain / Rancangan}

Merupakan hasil dari terjemahan analisis kebutuhan yang kemudian disusun menjadi sebuah rancangan atau detail prosedural untuk diimplementasikan. Proses desain atau rancangan akan berfokus pada usecase diagram dan activity diagram.

Use Case Diagram untuk menjelaksan interaksi penggunan dengan aplikasi. Use Case Diagram user dapat dilihat pada gambar 2 .

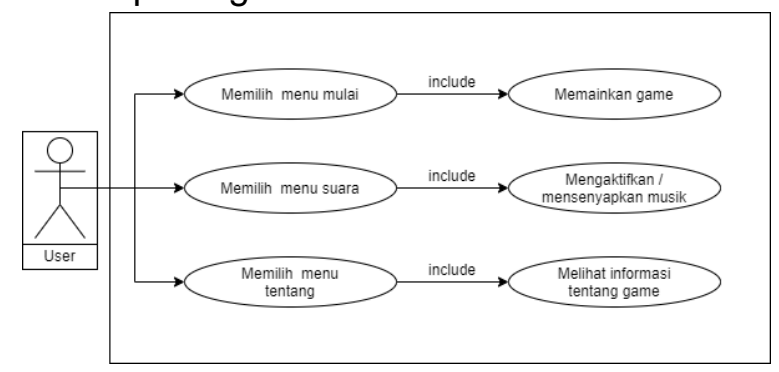

Gambar 2. Use Case User

Activity Diagram menjelaskan cara kerja atau alur kerja system pada sebuah aplikasi. Activity Diagram menu utama terdapat pada pada gambar 3 .

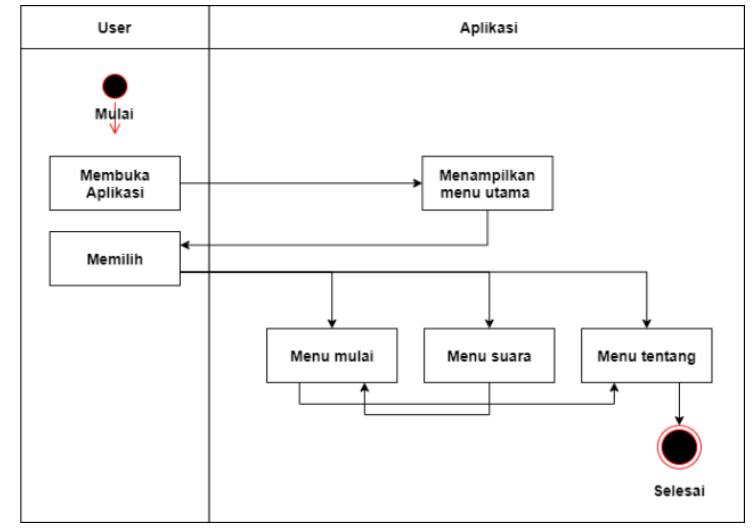

Gambar 3. Activity Diagram Menu Utama

\section{Implementasi / Penerapan}

Penelitian (Fithri \& Setiawan, 2017) menerangan tahap ini, proses penerapan dan pengujian hasil perancangan berlangsung. Dengan membuat kode program sesuai dengan detail prosedural usecase diagram, activity diagram, dan storyline yang sudah dibuat agar terbentuk sebuah sistem yang dapat memenuhi harapan.

\section{Integrasi \& Pengujian}

Pengujian dilakukan sebelum aplikasi diterapkan dan diujikan ke anak-anak aplikasi akan diuji menggunakan black box testing. Mengutip dari (Prasetyo et al., 2017) pengujian dilakukan dengan maksud untuk mengetahui batasan sampai mana program aplikasi mampu menampilkan informasi atau output yang diinginkan oleh pengguna.

Rangkaian fase metode waterfall yang penulis gunakan diatas jika divisualisasikan maka akan seperti gambar 4.

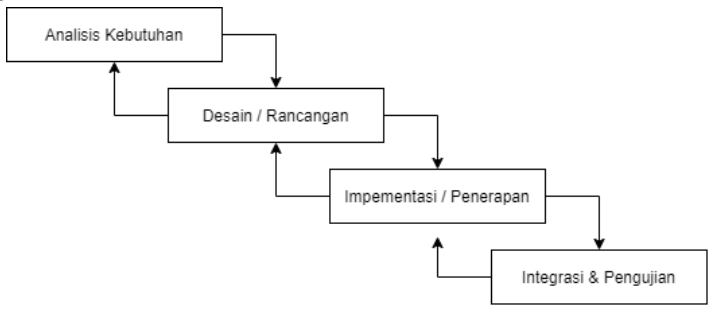

Gambar 4. Metode Waterfall 


\section{HASIL DAN PEMBAHASAN}

\section{A. Game Interface}

Terdapat beberapa tampilan atau interface pada aplikasi ini. Pertama interface menu utama, interface menu mulai, interface menu suara, dan interface menu tentang / kredit.

Interface Menu Utama, Pertama kali aplikasi dieksekusi akan muncul tampilan menu utama yang terdapat tiga pilihan menu antara lain mulai, suara, dan tentang (kredit). Menu mulai untuk menjalankan pemainan dari level satu, menu suara untuk mengaktifkan dan mensenyapkan suara pemainan, terdapat tombol aktif, senyap, dan kembali, menu tentang / kredit akan menampilkan tentang informasi aplikasi, terlihat pada gambar 5 .

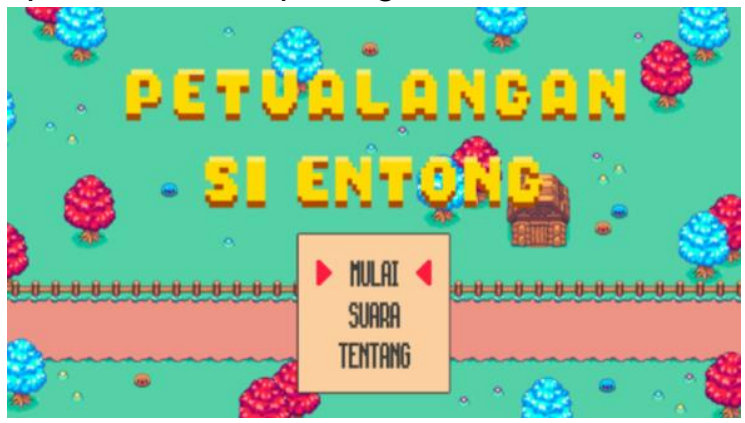

Gambar 5. Tampilan Menu Utama

Interface Menu Mulai akan menjalankan permainan dari level 1 saat permainan dimulai akan menampilkan petunjuk yang akan menjelaskan bagaimana cara permainan seharusnya dimainkan, target poin setiap level, dan edukasi singkat tekait makanan bergizi masing-masing level, setelah itu mulai kedalam game utama level. Jika target poin sudah terkumpul akan mucul tampilan hasil dari level permainan saat ini. Berikut tampilan level 1 terdapat pada gambar 6 .

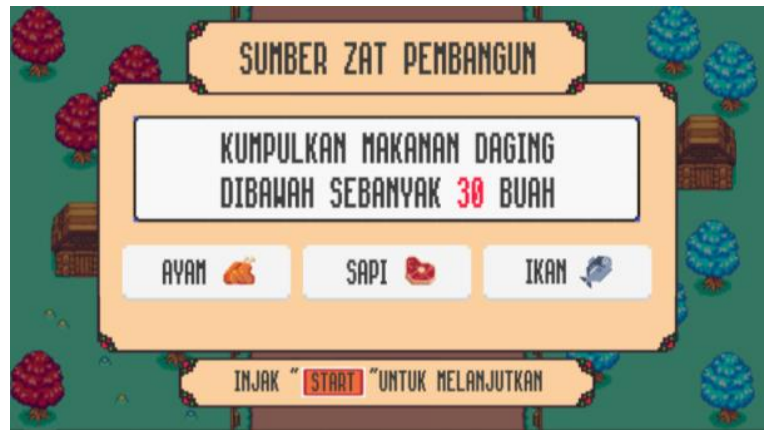

(a)

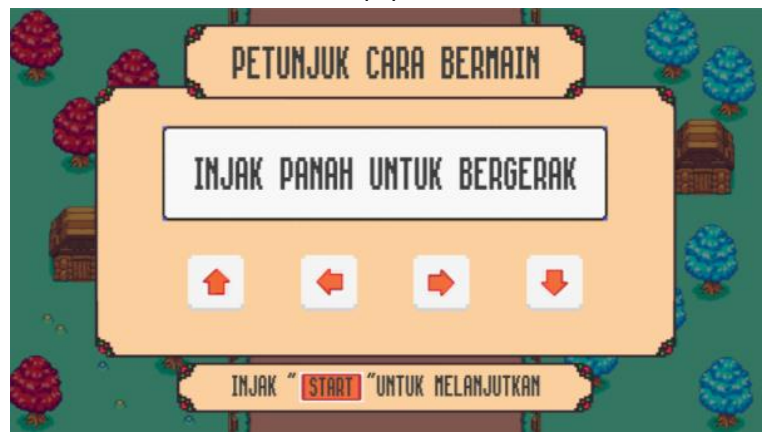

(b)

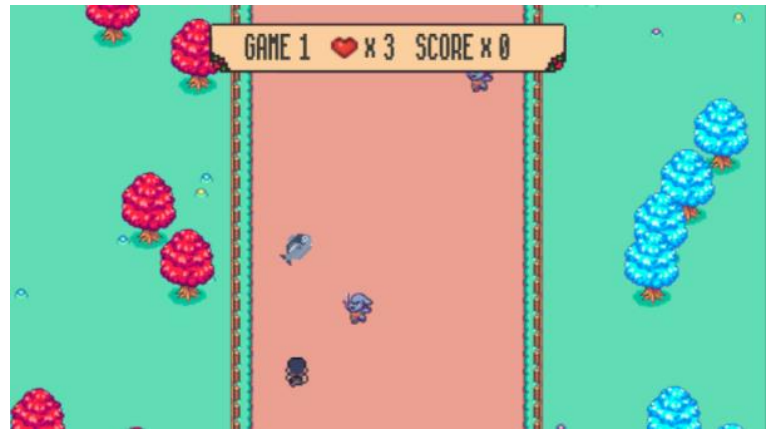

(c)

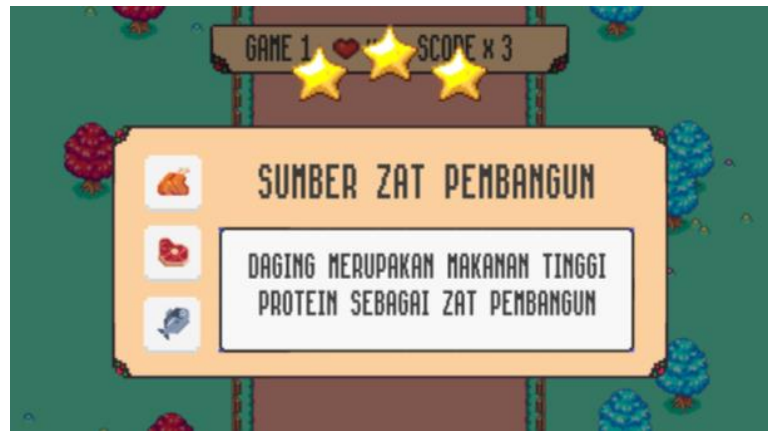

(d)

Gambar 6. Tampilan petunjuk poin (a), Tampilan petunjuk gerak (b), Tampilan game utama level (c), Tampilan hasil (d).

Interface Menu Suara terdapat pilihan menu aktif untuk mengaktifkan musik permainan, pilihan menu senyap untuk mensenyapkan suara pemainan, dan pilihan menu kembali untuk kehalaman 
menu utama. Tampilan menu suara dapat dilihat pada gambar 7 .

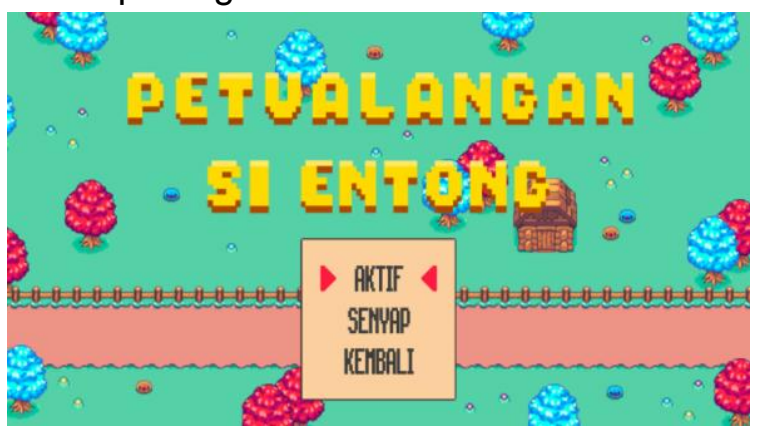

Gambar 7. Tampilan Menu Suara

Interface Menu Tentang / Kredit menampilkan tentang informasi terkait aplikasi yang dibuat, alat apa saja yang digunnakan dan pihak yang terlibat dalam pembuatan aplikasi. Sesuai pada gambar gambar 8.

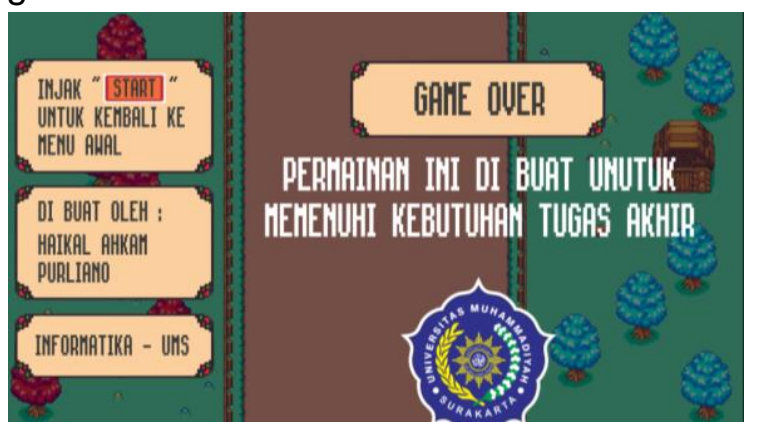

Gambar 8. Tampilan Menu Tentang

\section{B. Pengujian Black Box}

Sesuai penelitian (Setyawidi et al., 2016) pengujian black box merupakan pengujian tanpa memperhatikan struktur logik internal perangkat lunak. Metode ini digunakan untuk mengetahui apakah perangkat lunak berfungsi dengan benar. Hasil uji aplikasi menghasilkan tabel sebagai berikut.

Tabel 3. Hasil Uji Black Box

\begin{tabular}{lllll}
\hline No. & Unit & Input & Output & Hasil \\
\hline 1. & Menu & Tombol & Memulai & Ok \\
& Utama & Mulai & $\begin{array}{l}\text { permainan } \\
\text { dari level 1 }\end{array}$ & \\
& & Menampilkan & \\
& & Tombol & Ok \\
& Suara & pengaturan & \\
& & suara & \\
& & Menampilkan & Ok \\
& & menu info & \\
& &
\end{tabular}

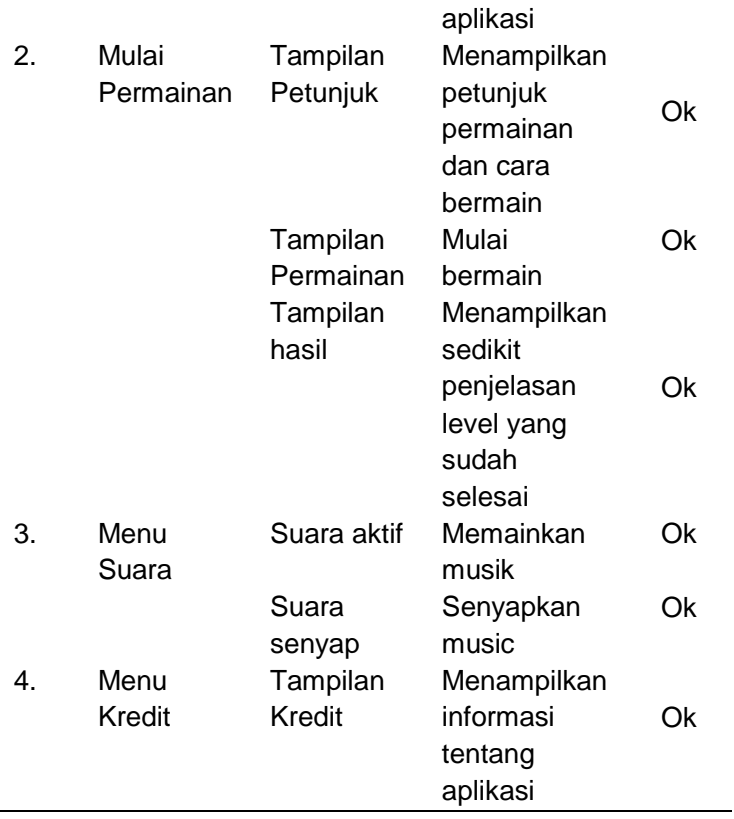

Berdasarkan data tabel diatas menunjukan bahwa permainan sudah berjalan sesuai spesifikasi kebutuhan yang menampilkan hasil uji.

\section{Kesimpulan}

Hasil kesimpulan menunjukan bahwa aplikasi game edukasi ini membahas tentang beberapa makanan bergizi yang memiliki sumber protein, vitamin, dan karbohidrat. Perancangan game didesain memiliki tiga variasi level, memiliki sebuah karakter, dan rintangan yang bervariasi agar pemain lebih tertarik, untuk memainkan pemain harus menggunakan step pad sebagai controller. Pembuatan aplikasi dirancang dengan metode SDLC Waterfall dan dibangun menggunakan Construct 2. Aplikasi telah diuji coba melalui black box testing menunjukan hasil yang sudah sesuai dengan spesifikasi kebutuhan aplikasi. 


\section{DAFTAR PUSTAKA}

Abidin, Z., Hasan, W. M., \& Mustain. (2017). Game Tradisional Go Egrang Berbasis Android. J-TIIES, 1(1), 4658.

Al-Azawi, R., Al-Faliti, F., \& Al-Blushi, M. (2016). Educational Gamification Vs. Game Based Learning: Comparative Study. International Journal of Innovation, Management and Technology, 7(4), 131-136. https://doi.org/10.18178/ijimt.2016.7.4. 659

Darmanto, B., \& Sudarmilah, E. (2016). Game Edukasi Dampak Pergaulan Bebas. PROtek: Jurnal IImiah Teknik Elektro, 3(2). https://doi.org/10.33387/protk.v3i2.149

Devrizal, Rini, R., \& Fatmawati, N. (2019). Permainan Tradisional Meningkatkan Kemampuan Motorik Kasar Anak di PAUD Cahaya Kartini Bandar Lampung. JPA - Jurnal Pendidikan Anak, 5(2).

Firdaus, M., \& Nugroho, H. W. (2016). Rancang Bangun Game Edukasi Asah Otak Anak Berbasis Android Menggunakan Aplikasi Construct 2. KONVERGENSI, 12(1), 1-10.

Fithri, D. L., \& Setiawan, D. A. (2017). Analisa Dan Perancangan Game Edukasi Sebagai Motivasi Belajar Untuk Anak Usia Dini. SIMETRIS, 8(1), 225-230. https://doi.org/10.24176/simet.v8i1.95 9

Jin, G., Tu, M., Kim, T.-H., Heffron, J., \& White, J. (2018). Evaluation of GameBased Learning in Cybersecurity Education for High School Students. Journal of Education and Learning (EduLearn), 12(1), 150.

https://doi.org/10.11591/edulearn.v12i 1.7736

Kusuma, G. A., \& Sudarmilah, E. (2016). Pengembangan Permainan Labirin untuk Membantu Perkembangan Motorik Anak. PROtek, 3(2), 46-89.

Masfufah, E., Rohman, M. G., \& Susiolo, P. H. (2017). Aplikasi Game Petualangan Si Kancil Berbasis Android.
JOUTICLA, 3(2), 57-66.

https://doi.org/10.30736/jti.v2i2.65

Papastergiou, M. (2009). Digital Game-

Based Learning in high school

Computer Science education: Impact

on educational effectiveness and student motivation. Elsevier

Computers and Education, 52(1), 1-

12.

https://doi.org/10.1016/j.compedu.200 8.06.004

Pérez, M. E. del, Alba, P. G. D., \& García, L. C. F. (2018). Game-Based Learning: Increasing the LogicalMathematical , Naturalistic, and Linguistic Learning Levels of Primary School Students. NAERJ, 7(1), 31-39. https://doi.org/10.7821/naer.2018.1.24 8

Prasetyo, A., Zamroni, M. R., \& Sholihin, M. (2017). Aplikasi Game Legenda Bukit Mayangkara Berbasis Android. J-TIIES, 1(1), 573-578.

Putra, D. W., Nugroho, A. P., \& Puspitarini, E. W. (2016). Game Edukasi Berbasis Android Sebagai Media Pembelajaran Untuk Anak Usia Dini. JIMP, 1(1), 4658.

https://doi.org/10.24176/simet.v8i1.95 9

Rahman, Z., Mustain, \& Wahyudi, M. H. (2017). Game Edukasi Recycle Barang Bekas Bebasis Android. JTIIES, 1(1), 445-452.

Setyawidi, L., Kridalukmana, R., \& Martono, K. T. (2016). Pembuatan Aplikasi Permainan "Ayo Sehat" Berbasis Android. JTSiskom, 4(2), 315-321. https://doi.org/10.14710/jtsiskom.4.2.2 016.315-321

Tahir, R., \& Wang, A. I. (2020). Codifying game-based learning: Development and application of leaguÊ framework for learning games. Electronic Journal of E-Learning, 18(1), 69-87. https://doi.org/10.34190/JEL.18.1.006 